\title{
Pendampingan Pemasaran Industri Rumahan Keripik Tempe Khas Trenggalek Berbasis Online di Kelurahan Ngantru Sebagai Produk Makanan Unggulan Kabupaten Trenggalek
}

\author{
Angga Setiawan', Herlina Puji Utami², Putri Datalia Jatayu ${ }^{3}$ \\ STKIP PGRI Trenggalek
}

\begin{tabular}{|c|c|}
\hline (A) Check for updates open 0 access (c) & DOI: https://doi.org/10.53621/jippmas.v1i2.68 \\
\hline Informasi Artikel & ABSTRAK \\
\hline Riwayat Artikel: & Industri keripik tempe di Kelurahan Ngantru tidak dapat berkembang secara \\
\hline Diterima: 30 Oktober 2021 & siginifikan diakrenakan terdapat industri lain yang berada di Desa Bendorejo \\
\hline Revisi Akhir: 14 Desember 2021 & yang lokasinya lebih strategis di pinggir jalan nasional dan pemasaran keripik \\
\hline Disetujui: 18 Desember 2021 & tempe di Kelurahan Ngantru sangat terbatas untuk pemenuhan pasar lokal \\
\hline Terbit: 31 Desember 2021 & serta kondisi tersebut diperparah pada masa pandemi covid-19. Salah satu \\
\hline Kata Kunci: & solusi yang dapat menyelesaikan permasalahan tentang pemasaran industri \\
\hline Pemasaran online & keripik tempe yaitu melalui pemasaran secara online. Hasil yang diperoleh \\
\hline Produk Makanan & setelah mengimplementasikan pemasaran secara online kepada pengusaha \\
\hline Keripik tempe & $\begin{array}{l}\text { UMKM keripik tempe adalah adanya perubahan pola pikir dan kesadaran } \\
\text { pengusaha keripik tempe untuk menjual keripik tempe, pengetahuan }\end{array}$ \\
\hline 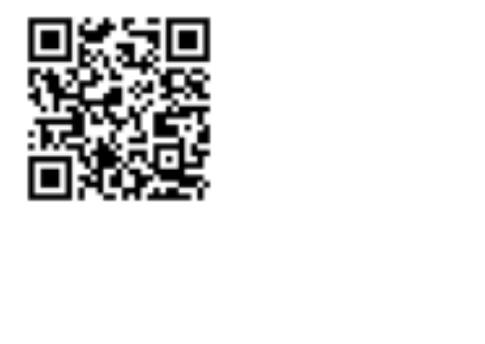 & $\begin{array}{l}\text { pengusaha tentang strategi pemasaran berbasis online melalui e-commerce } \\
\text { atau market place meningkat, jangkauan pasar pemasaran keripik tempe } \\
\text { semakian meluas tidak hanya pemenuhan pasar lokal dan perubahan omset } \\
\text { penjualan yang semakin naik dikarenakan kenaikan permintaan pasar yang } \\
\text { tidak hanya pasar lokal namun juga pasar nasional. Tata kelola manajemen } \\
\text { pemasaran semakin baik dengan dibentuknya paguyupan pengusaha keripik } \\
\text { tempe yang bertujuan untuk melakukan diskusi secara rutin, baik dengan } \\
\text { antar pengusahana, kelurahan, maupun pemerintahan kabupaten } \\
\text { Trenggalek. }\end{array}$ \\
\hline
\end{tabular}

\section{PENDAHULUAN}

Tempe menjadi suatu makanan khas yang dimiliki oleh orang Indonesia, tempe mempunyai banyak mengandung khasiat. Tempe mengandung isoflavon yang berperan penting sebagai pangan fungsional untuk wanita yang sudah mengalami menopause (Deoranto \& Astusi, 2019). Di dunia kesehatan tempe mempunyai peran mencegah dan mengobati berbagai penyakit antara lain jantung, kolestrerol dan hypertensi (Dinar, 2013). Tempe dapat diolah dengan berbagai inovasi seseuai pernyataan (Suryanti \& Mediaswanti, 2017) inovasi tempe sangat beragam karena tempe bisa diolah menjadi makanan atau jajanan khas, salah satu inovasinya diolah menjadi keripik tempe. Kabupaten Trenggalek mempunyai industri kecil yang berdiri sejak tahun 1990-an dan masih berkembang hingga saat ini yaitu industri keripik tempe. Sentra industri keripik tempe pertama di Kabupaten Trenggalek terletak di Kelurahan Ngantru. Jumlah industri rumahan keripik tempe kurang lebih sebanyak 30 pengusaha keripik tempe. Menurut (Kusumaningsih,2018) Keripik tempe dapat dimakan sebagai pendamping lauk atau sebagai makanan cemilan. Keripik tempe menjadi makanan oleh-oleh wajib wisatawan ketika berkunjung di Kabupaten Trenggalek, Keripik tempe Kelurahan Ngantru mempunyai rasa yang renyah dan gurih. Sehingga jika pernah merasakan keripik tempe ini akan ketagihan untuk mencobanya kembali. Di era teknologi yang semakin canggih pemasaran keripik tempe tidak hanya dijual melalui toko offline saja tetapi melalui toko online. Menurut (Fadly \& Sutama, 2020) pemasaran online merupakan komponen dalam e-commerce. Dimana e-commerce adalah sistem jual beli online. Pemasaran onlin 
sebagai komponen dalam e-commerce yakni sebagai strategi produksi, distribusi, penetapan harga, dan promosi melalui media digital (Nurani \& Widhajati, 2019). Dapat diartikan bahwa segala macam proses pemasaran dari sebuah produk atau jasa hingga ke tangan pembeli semua menggunakan media digital. Sejalan dengan itu, (Shiratina et al., 2020) berpendapat bahwa pemasaran online adalah pendukung sebuah konsep pemasaran modern. Konsep tersebut berupa segala macam bentuk promosi dan penjualan produk atau jasa melalui internet. Pemanfaatan internet menjadi andalan dalam melakukan pemasaran online melalui media sosial, jasa pengiklanan, toko online, dan masih banyak lagi (Siti, 2018). Jadi pada intinya pemasaran online adalah usaha yang dilakukan untuk mempromosikan produk atau jasa dengan menggunakan internet.

Masalah yang timbul sesuai fakta dilapangan yaitu pemasaran keripik tempe di Kelurahan Ngantru sangat terbatas untuk pemenuhan pasar lokal. Sehingga pemasaran keripik tempe belum mampu menjangkau ke luar kabupaten Trenggalek dan belum banyak dikenal oleh masyarakat luas dan kondisi tersebut diperparah pada masa pandemi covid-19 yang menyebabkan omset penjualan menurun, solusi yang dihadirkan oleh peneliti yaitu pemasaran keripik tempe melalui pemasaran secara online (S.Nirmalasari,2017). Sehingga nanti harapnnya industri keripik tempe Kelurahan Ngantru bisa berkembang dengan pesat dan menjadi makanan unggulan khas Kabupaten Trenggalek yang dikenal oleh semua kalangan tidak hanya didalam kota tetapi luar kota.

\section{PERMASALAHAN}

Pengusaha keripik tempe di Kelurahan Ngantru menjajakan keripik tempe di depan rumah mereka. Dinas Koperasi dan Perdagangan Kabupaten Trenggalek mengurus perizinan bagi Industri keripik tempe di Kelurahan Ngantru. Pengurusan izin digratiskan oleh Dinas Koperasi dan UMKM Kabupaten Trenggalek, tujuannya agar pengusaha keripik tempe lebih mudah untuk memasarkan produk keripik tempe di toko-toko, supermarket, maupun bazar yang diadakan oleh pemerintah Kabupaten Trenggalek atau pemerintah kota lain. Namun usaha yang dilakukan pemerintah Kabupaten Trenggalek untuk mengangkat industri keripik tempe tidak berdampak optimal karena jumlah pengusaha keripik tempe relatif tetap dan tidak ada peningkatan jumlah produksi maupun permintaan pasar.

Penyebab industri keripik tempe di Kelurahan Ngantru tidak dapat berkembang yaitu muncul industri keripik tempe baru di Desa Bendorejo yang lokasinya lebih strategis di pinggir jalan nasional, sedangkan industri keripik tempe di Kelurahan Ngantru berada di jalanan kecil yang jarang dilewati oleh kendaraan dari luar kota. Selain itu varian produk makanan oleh-oleh yang dijual beragam tidak hanya keripik tempe, serta jumlah pengusaha keripik tempe lebih banyak dan kuantitasnya terus meningkat (Laksono et al., 2019). Permasalahan lain yang belum dapat dipecahkan hingga saat ini yaitu tentang pemasaran keripik tempe. Pemasaran keripik tempe di Kelurahan Ngantru sangat terbatas untuk pemenuhan pasar lokal. Sehingga pemasaran keripik tempe belum mampu menjangkau ke luar kabupaten Trenggalek dan belum banyak dikenal oleh masyarakat luas. Jika permintaan pasar lokal menurun akan berakibat kepada jumlah produksi dan penurunan omset pengusaha keripik tempe. Kondisi tersebut diperparah pada masa pandemi covid-19, dimana semua tempat wisata di Kabupaten Trenggalek tutup untuk menghindari penyebaran virus Covid-19, yang tentunya mengakibatkan penurunan jumlah wisatawan untuk datang ke kabupaten Trenggalek dan berpengaruh 
terhadap perekonomian masyarakat. Kondisi tersebut berdampak langsung terhadap penjualan keripik tempe yang pemasarannya hanya mengandalkan jumlah pengunjung atau wisatawan yang datang. Jika permasalahan ini terus dibiarkan akan berakibat terhadap kelangsungan industri keripik tempe yang akan gulung tikar. Padahal jika industri keripik tempe di kelola dengan baik dan strategi pemasaran tepat, keripik tempe yang diproduksi oleh industri keripik tempe di kelurahan Ngantru akan berkembang dengan pesat dan menjadikan Keripik tempe Kelurahan Ngantru sebagai makanan unggulan Kabupaten Trenggalek. Karena Rasa keripik tempe yang diproduksi oleh industri rumahan di Kelurahan Ngantru mempunyai cita rasa yang khas, enak, gurih, dan renyah.

Berdasarkan permasalahan yang telah dipaparkan di atas, salah satu solusi yang dapat menyelesaikan permasalahan tentang pemasaran industri keripik tempe yaitu melalui pemasaran secara online. Beberapa keuntungan pemasaran yang dilakukan secara online yaitu biaya pemasaran lebih murah, kemudahan dalam memilih target pasar, kemudahan mengelola barang, efektifitas dan efisiensi dalam menjual produk keripik tempe, dan permintaan pasar dari luar Kabupaten Trenggalek akan meningkat. Pemasaran keripik tempe berbasis online baik melalui ecommerce dan market place akan berdampak positif yaitu keripik tempe khas Kelurahan Ngantru akan dikenal oleh masyarakat luas dan tentunya akan meningkatkan omset pengusaha keripik tempe.

\section{METODE PELAKSANAAN}

Metode pelaksanaan Pendampingan pemasaran keripik tempe berbasis Online di Kelurahan Ngantru meliputi:

1. Identifikasi potensi dan masalah

Tim PHP2D melakukan observasi dan wawancara terkait industri rumahan keripik tempe di Kelurahan Ngantru. Pengusaha keripik tempe hanya menjual keripik tempe dalam skala lokal dan menjajakan dagangannya di depan rumah. Menurut (Suknia \& Rahmani, 2020) Jika industri keripik tempe dilakukan pemasaran secara tepat maka akan mengangkat industri keripik tempe karena rasa keripik tempe khas kelurahan Ngantru enak, renyah, dan gurih.

2. Proses dan hasil analisis kebutuhan masyarakat

Berdasarkan pemetaan masalah yang diperoleh bahwa, kebutuhan industri keripik di kelurahan Ngantru yaitu dibutuhkan pendampingan terhadap pemasaran keripik tempe agar dapat dikenal masyarakat luas dan dapat menembus pasar nasional. Salah satu strategi pemasaran yang dapat dilakukan untuk memperkenalkan keripik tempe tersebut melalui pemasaran online baik melalui e-commerce dan market place(Asse et al., 2018).

3. Penselarasan dengan kebijakan pembangunan wilayah setempat

Tim PHP2D membangun koordinasi dan komunikasi dengan Pemerintahan KelurahanNgantru untuk menyelaraskan program PHP2D dengan kebijakan yang sudah disusun oleh Kelurahan Ngantru. Kedua program yang sudah diselaraskan akan bersinergi untuk mewujudkan tujuan bersama dalam mengembangkan industri keripik tempe di Kelurahan Ngantru.

4. Penyusunan program bersama masyarakat

Tim PHP2D melakukan Focus Group Discussion (FGD) untuk menyusun program bersama tentang Strategi Pemasaran Keripik Tempe di Kelurahan Ngantru, sehingga 
program yang telah disusun tepat sasaran, berjalan sesuai rencana yang telah disusun dan mampu meningkatkan penjualan keripik tempe.

5. Penetapan khalayak sasaran

Sasaran PHP2D yaitu pengusaha industri keripik tempe di Kelurahan Ngantru yang mempunyai permasalahan tentang strategi pemasaran agar keripik tempe dapat dikenal oleh masyarakat luas dan menembus pasar interlokal dan nasional.

6. Perumusan dan pengukuran indikator keberhasilan

Perumusan dan pengukuran indikator dilakukan oleh Tim PHP2D agar program yang dilakukan dapat berjalan sesuai tujuan yang sudah dirancang dan mampu mengukur tingkat keberhasilan serta hambatan yang ditemui ketika program berjalan.

7. Pelaksanaan program

Pelaksanaan program dilakukan dengan pendampingan terhadap pengusaha keripik tempe. Pendampingan tersebut yaitu dengan melakukan pengajaran dan pendampingan secara rutin tentang penjualan melalui e-commerce dan market place serta strategi marketing yang efektif dan efisien dalam memasarkan keripik tempe dalam skala luas dan mempunyai hasil maksimal.

8. Penguatan dukungan desa terhadap pelaksanaan program

Pada pelaksanaan program pendampingan pemasaran berbasis online melibatkan unsur perangkat kelurahan sehingga dengan dukungan pihak kelurahan akan meningkatkan kinerja Tim PHP2D agar program yang telak dilaksanakan berhasil.

9. Analisis tingkat keberhasilan program

Untuk mengetahui tingkat keberhasilan program yaitu dengan cara memetakan keberhasilan program yang sudah berjalan dan yang belum. Melalui analisis tingkat keberhasilan diharapkan program yang belum berjalan akan dievaluasi, sehingga seluruh indikator ketercapaian program dapat berjalan secara optimal (Wahyujatmiko \& Yon Hadi, 2018).

10. Perintisan kemitraan dengan berbagai pihak

Melalui Program PHP2D melalui pendampingan pengusaha keripik tempe di Kelurahan Ngantru dapat menjalin kemitraan dengan berbagai pihak seperti Dinas Koperasi dan UMKM, dan Dinas Komunikasi dan Informatika sehingga programprogram selanjutnya mendapat dukungan oleh dinas terkait.

11. Penguatan jejaring koordinasi dan komunikasi antar kelembagaan lokal

Tim PHP2D secara rutin memberikan sosialiasi kepada kelembagaan lokal seperti LKMD, PKK, dan RW sehingga program pendampingan pengusaha keripik tempe ini mendapat dukungan oleh kelembagaan lokal yang secara langsung akan memperlancar pelaksanaan program yang dilaksanakan.

12. Monitoring dan evaluasi berdsarkan indikator keberhasilan program

Tahap monitoring dilakukan agar proses keberlanjutan oleh tim pengelola dari masyarakat tentunya masih membutuhkan pembimbingan dalam proses pelaksanaan program. (Qgdqj \& Imanuel, 2013) tujuan dari tahap monitoring adalah sebagai berikut:

a. Melihat perkembangan program yang telah di laksanakan.

b. Mengetahui kendala yang ada dalam proses pelaksanaan program.

c. Mencari solusi terhadap masalah yang ada sehingga program pendampingan pemasaran keripik tempe berbasis online dapat dilaksanakan benar-benar efektif dan maksimal serta bersinergi. 
Tahap Evaluasi dilakukan untuk mengetahui kekurangan dalam pelaksanaan program (Jati \& Yuliansyah, 2017). Melalui proses Evaluasi, kekurangan yang terjadi dalam pelaksanaan program dapat diperbaiki menjadi lebih baik. Tahap ini di lakukan oleh Tim PHP2D (Mahasiswa dan Dosen) bersama Pemerintahan Kelurahan Ngantru dan Pengusaha keripik tempe.

13. Lokakarya hasil

Lokakarya hasil dilakukan di STKIP PGRI Trenggalek dengan mengundang Dinas terkait, Lurah Kelurahan Ngantru, Pengusaha Keripik tempe, dan pimpinan, dosen, staff STKIP PGRI Trenggalek guna memaparkan hasil pelaksanaan program penampingan pengusaha keripik tempe berbasis online serta publikasi yang sudah dilakukan.

14. Pelaporan

Pelaporan dibagi kedalam 2 (dua) tahap yaitu.

a. Pelaporan Awal

Pelaporan awal disesuaikan dengan hasil yang telah dicapai selama melakukan pendampingan terhadap pengusaha keripik tempe. Memaparkan proses pelaksanaan program dari awal hingga akhir serta perkembangan dari setiap program yang telah dilaksanakan.

b. Pelaporan akhir

Pelaporan akhir dilakukan setelah melakukan revisi laporan apabila terjadi kesalahan dalam pembuatan laporan agar dalam penyusunan laporan akhir diperoleh hasil yang lebih baik dari laporan awal.

15. Pemutakhiran data sasaran 2 bulan pasca program

Pemutakhiran data sasaran dilakukan setelah pelaksanaan program guna untuk mengetahui keberlanjutan program setelah pendampingan oleh Tim PHP2D selesai.
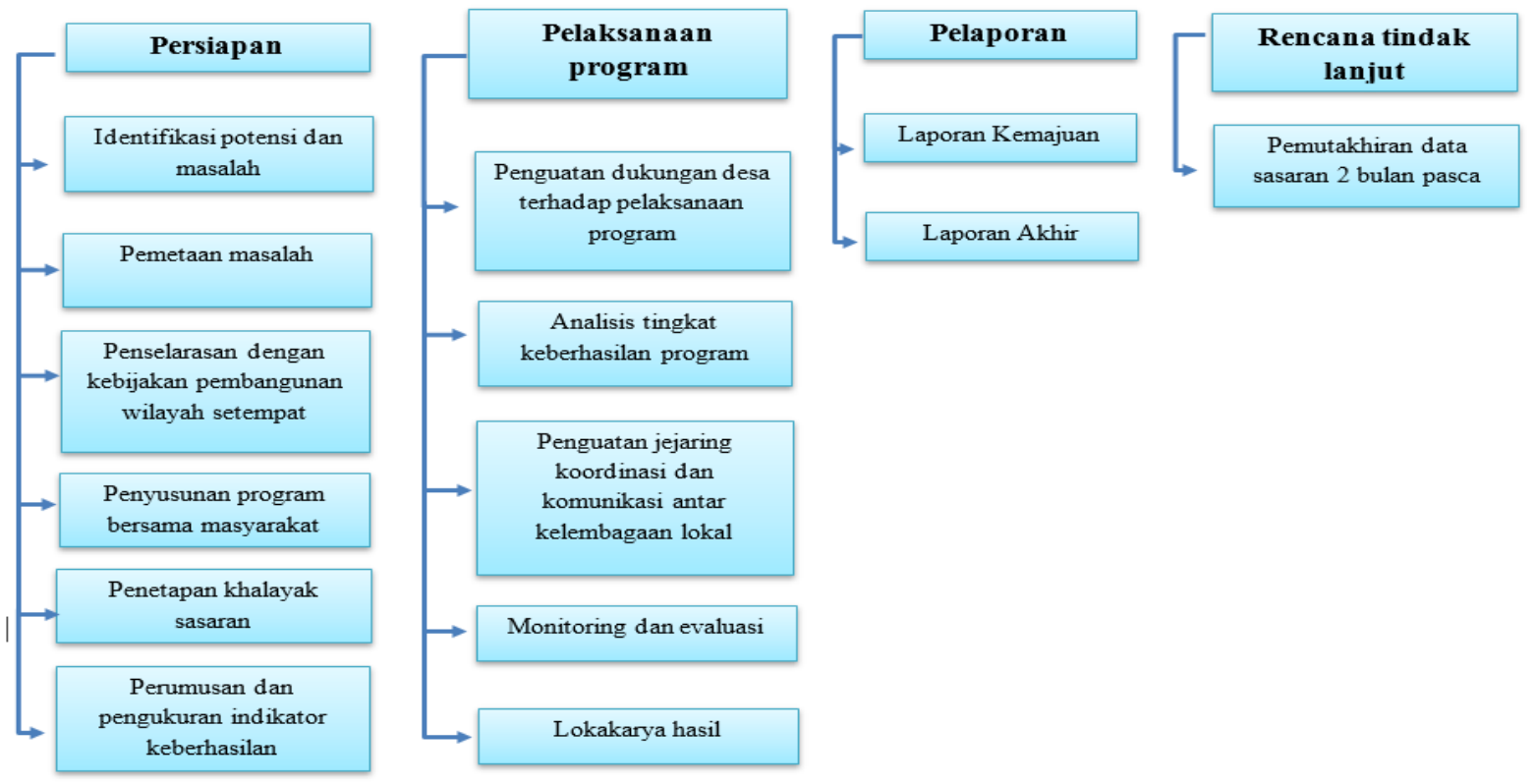

Gambar 1. Pelaksanaan pendampingan pemasaran keripik tempe berbasis Online 


\section{PELAKSANAAN}

Kegiatan yang telah dilakukan tim PHP2D meliputi:

1. Sosialisasi

Kegiatan sosialisasi ini di laksanakan pada tanggal 9 September 2021. Sosialisasi ini dihadiri oleh Dinas Koperasi dan Usaha Mikro dan Perdagangan Kabupaten Trenggalek dan mitra yang bersangkutan.

Kegiatan Sosialisasi membentuk Paguyuban Pengusaha Keripik Tempe, Tim Marketing, dan Publikasi media Massa.

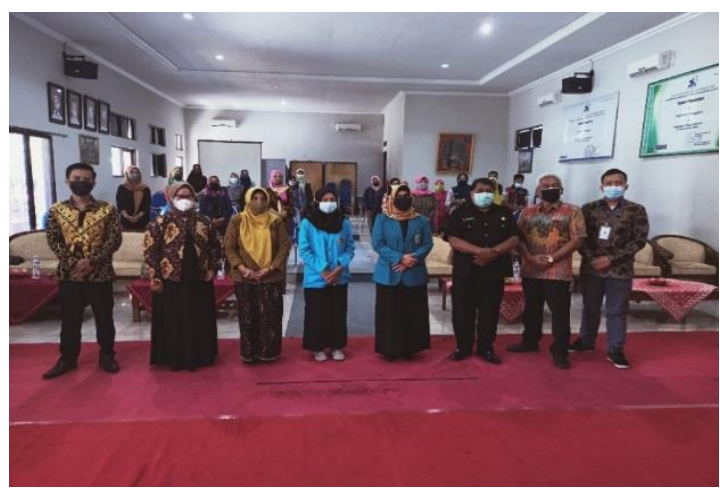

Gambar 2. Kegiatan Sosialisasi, Pembentukan Paguyuban dan Tim Marketing

2. Pelatihan Tim Marketing

Kegiatan pelatihan dilaksanakan pada tanggal 23 September 2021. Kegiatan pelatihan ini meliputi kegiatan membuat akun shoppe, foto produk dan pembuatan logo toko.

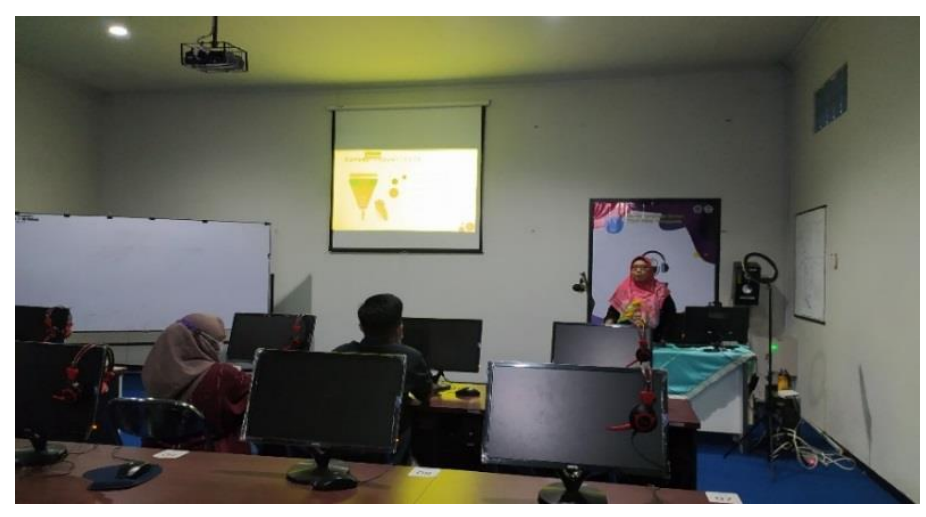

Gambar 3. Kegiatan Pelatihan Tim Marketing

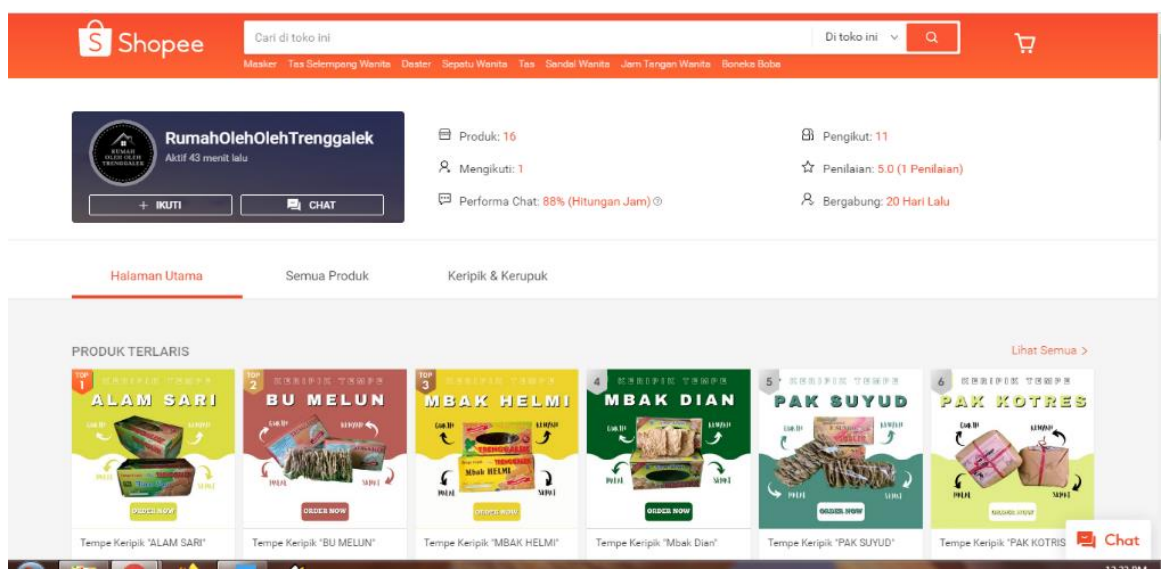

Gambar 4. Pembuatan akun Shoppe 

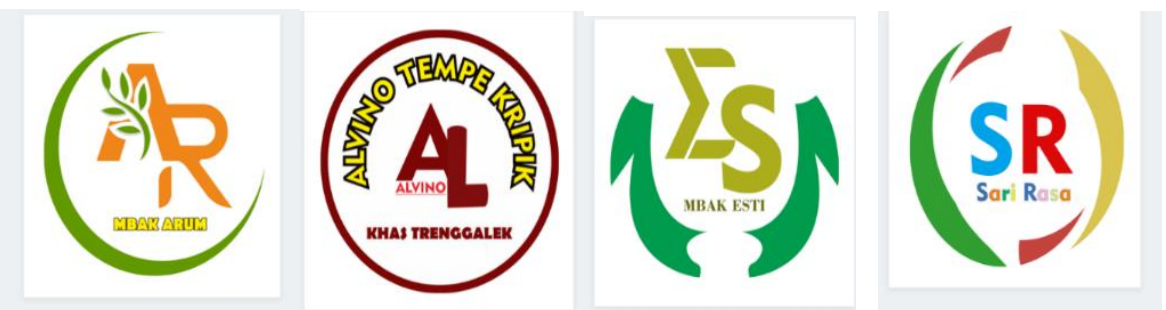

Gambar 5. Pembuatan Logo toko
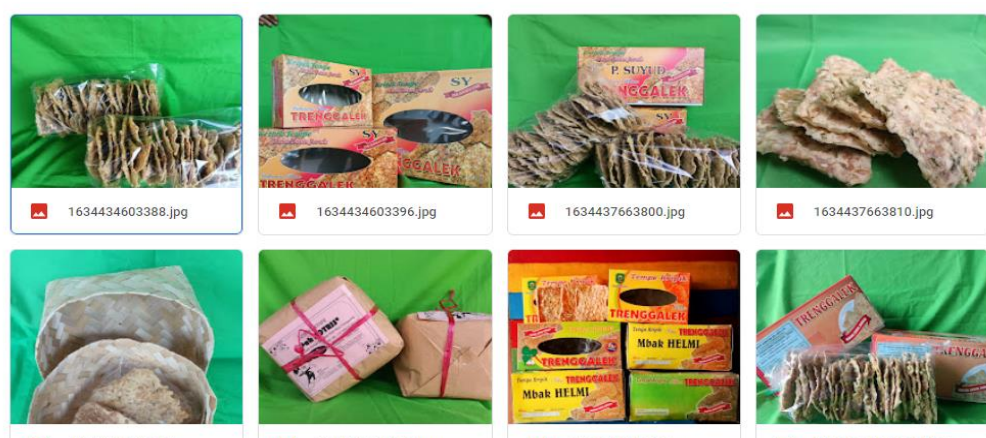

- $1634437663810 . j p g$

『 1634447224006.jpg

• $1634447224013 . j p g$

๑ 1634624167200.jpg

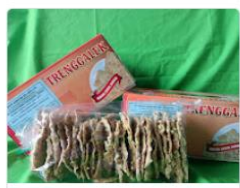

Gambar 6. Foto Produk

3. Pendampingan

Kegiatan Pendampingan dimulai pada Minggu 1 Bulan Oktober 2021.

Kegiatan Pendampingan yaitu kegiatan Promosi Penjualan di akun Shoppe.

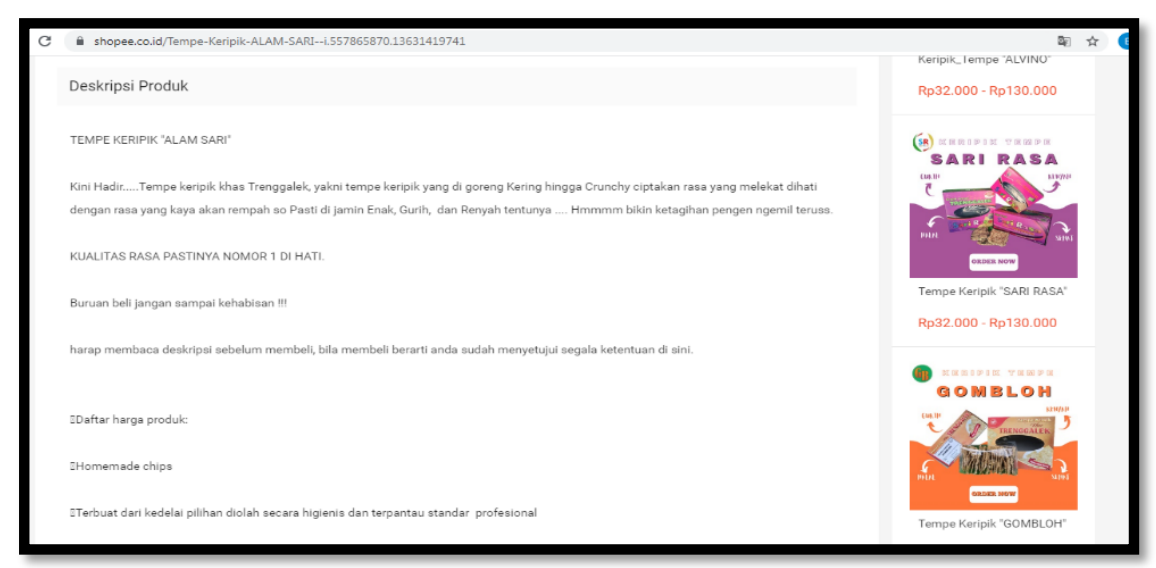

Gambar 7. Promosi Penjualan

\section{HASIL DAN DISKUSI}

Sosialisasi yang diselenggarakan oleh tim PHP2D dengan bekerja sama pihak Dinas Koperasi dan Usaha Mikro dan Perdagangan Kabupaten Trenggalek memberikan pemahaman tentang pemasaran online kepada pihak pengusaha UMKM keripik tempe, manfaat dari pemasaran online yang didapatkan antara lain untuk memperluas jangkauan penjualan tidak hanya dari lingkup nasional tetapi internasional dan menambah omset penjualan (Nurani \& Widhajati, 2019). Tim PHP2D membentuk rumah pagayuban pengusaha keripik tempe. Dalam hukum adat paguyuban desa bisa diartikan sebagai suatu hubungan yang masing-masing saling mengahadapi dan melengkapi satu sama lain untuk memperoleh tujuan bersama (Rimawati, 2015). Paguyuban pengusaha 
keripik tempe yang sudah dibentuk diharapkan mempunyai hubungan yang baik dalam berbagai perasaan, seperti simpat, tolong menolong dan solidaritas yang terlepas dari perhitungan laba atau rugi untuk diri pribadi. Tim PHP2D membentuk susunan organisasi paguyuban dengan melihat keputusan pihak pengusaha, setelah susunan organisasi terbentuk tim PHP2D memberikan penjelasan dan pemahaman tentang jobdesk masing-masing organisasi. Tim marketing pemasaran dibentuk dengan meminta petunjuk dari pihak kelurahan, tim marketing difokuskan kepada individu yang belum memperoleh lapangan pekerjaan dan mampu menguasai ilmu pengetahuan dan teknologi. Tugas dari tim marketing sesuai dengan keputusan yang sudah disepakati bersama oleh tim PHP2D dan pengusaha keripik tempe:

1. Menganalisis dan menentukan target pasar yang ada di e-commerce atau market place

2. Analisis produk yang lebih disukai oleh konsumen, seperti varian rasa yang ada di keripik tempe yaitu rasa bawang dan daun jeruk, karena dengan melihat analisis produk maka tim marketing bisa memberikan informasi kepada pihak pengusaha untuk tetap menjaga dan meningkatkan cita rasanya.

3. Menetapkan harga yang saling menguntungkan antara pihak tim marketing dan pengusaha UMKM keripik tempe.

4. Mengemas produk keripik tempe agar tidak sampai pecah ditangan konsumen.

5. Memastikan kepuasan konsumen.

Untuk menjadikan tim marketing yang professional maka dibutuhkan suatu pelatihan maka tim PHP2D bekerja sama dengan seseorang yang ahli dalam berwirausaha secara online yang omsetnya sudah mencapai seratus juta lebih. Pelatihan yang dilakukan memakan waktu dua minggu, untuk minggu pertama tim marketing diberikan kiat-kiat menjadi tim marketing yang professional yang mampu menjual produk tidak hanya dari lingkup nasional tetapi lebih ke lingkup internasional sesuai dengan tujuan dan harapan tim PHP2D dan pengusaha UMKM bahwa keripik tempe ini bisa lebih dikenal dilingkup internasional. Tim marketing diberikan pelatihan untuk praktek membuat akun shoope, alasan tim PHP2D dan narasumber untuk memilih marketplace shopee karena merupakan marketplace yang digunakan oleh para penjual online di Indonesia. Sesuai pernyataan (Sulistiyawati \& Widayani, 2020) akun shopee menjadi situs penjualan online yang sangat diminati oleh masyarakat karena memiliki fitur dan kelebihan yang tidak dimiliki oleh marketplace lain. Tim marketing dilatih dua hari untuk membuat foto dan logo keripik tempe yang menarik konsumen yang menggunakan akun shopee. Setelah persiapan sudah siap diminggu kedua tim marketing diuji coba untuk menjual keripik tempe secara online dengan bekerja sama dengan tim PHP2D untuk menarik konsumen, tim PHP2D dan tim marketing menggaet dari pihak pemerintah daerah, perguruan tinggi, sekolah, keluarga dekat, teman dan masyarakat trenggalek untuk membeli produk keripik tempe secara online. Hasil keripik tempe yang dijual cukup banyak di hari uji coba dan sebagian konsumen merasa puas dengan cita rasa dan pengemasan produk. Sebagian konsumen sedikit kecewa karena keripik tempe yang diterima ada sebagian yang pecah. Melihat permasalahan yang timbul maka tim marketing dan narasumber kembali mengevaluasi pengemasan produk, pengemasan produk akhirnya diberikan bubble wrap didalam kemasan dan diluar kemasan untuk menjaga produk tidak pecah atau hancur sampai ditangan konsumen, sesuai dengan pernyataan (Sari dkk, 2018) untuk menjaga keripik tempe agar tidak mudah pecah ditangan konsumen maka diberikan sesuatu yang mampu menjaga produk tetap kuat didalam kemasan 
yaitu bubble wrap. Tim PHP2D menyerahkan sepenuhnya kepada tim marketing untuk mengelola pemasaran produk keripik tempe berbasis online, tetapi tim PHP2D juga memantau dan mengevaluasi perkembangan dari pemasaran online tersebut. Setelah program ini berjalan tiga bulan tim PHP2D mengevaluasi dari pihak pengusaha keripik tempe dengan menggunakan angket kepuasan dan butir wawancara. Sesuai dengan angket kepuasan dan wawancara yang dilakukan, pihak pengusaha memberikan feedback yang positif karena permintaan dari konsumen meningkat dari berbagai daerah dan omset yang didapatkan menjadi naik dari yang sebelumnya.

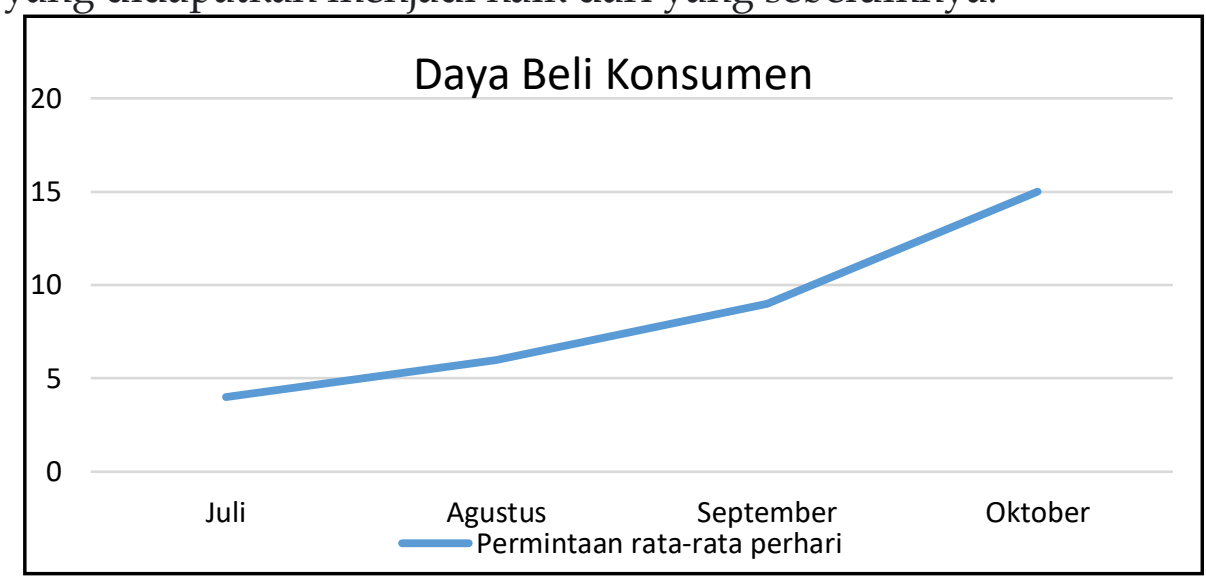

Gambar 8. Daya Beli Konsumen secara online

Tim PHP2D menyelenggarakan lokakarya dengan mengundang pengusaha UMKM keripik tempe dan tim marketing, hasil dari lokakarya pengusaha UMKM mengusulkan penjualan berbasis online tidak hanya untuk produk keripik tempe saja tetapi produkproduk lain yang menjadi jajanan khas Trenggalek juga ikut dipasarkan secara online, agar oleh-oleh khas trenggalek bisa lebih dikenal oleh khalayak luas. Menurut (Maulidasari \& Damrus, 2020) pemasaran online dianggap dapat memasarkan produk secara efektif dan efisien yang dapat menjangkau target konsumen/pelanggan dalam cakupan area yang tidak terbatas ruang maupun waktu. Sejalan dengan pendapat (Nisa et al., 2018) Manfaat dari pemasaran online yaiu memperluas dan mengembangkan pemasaran produk yang ada. Melihat feedback yang diberikan oleh pengusaha UMKM keripik tempe dengan adanya pemasaran online manfaat yang dirasakan begitu banyak dan pemasaran online tidak hanya fokus di satu marketplace saja tetapi lebih dari itu (Yuliani \& Widyakanti, 2020).

Tindak lanjut yang akan dilakukan tim setelah pelaksanaan kegiatan PHP2D, yaitu berupa pemantauan dan pendampingan terhadap jalannya pemasaran keripik tempe online yang dikelola oleh tim marketing.

\section{KESIMPULAN}

Kegiatan Pendampingan Pemasaran Industri Rumahan Keripik Tempe KhasTrenggalek Berbasis Online Di Kelurahan Ngantru Sebagai Produk Makanan Unggulan Kabupaten Trenggalek sudah berjalan sesuai dengan jadwal kegiatan yang telah disusun. Kegiatan ini mendapat dukungan dan respon yang sangat positif dari pihak pemerintah daerah dan para pelaku Usaha Keripik Tempe di Kelurahan Ngantru Kabupaten Trenggalek.

\section{SARAN}

Kegiatan pemasaran online keripik tempe ini tidak hanya di kelurahan Ngantru saja tetapi juga dapat meluas kepada semua industry di Kabupaten Trenggalek. 


\section{UCAPAN TERIMA KASIH}

Terimakasih kami ucapkan kepada Belmawa Kemdikbudristek kepada hibah PHP2D dengan nomor 172/E2/PPK/SPK/PHP2D/2021, Prodi PGSD STKIP PGRI Trenggalek dan Kampus tercinta STKIP PGRI Trenggalek yang memberikan support baik material dan spirit sehingga program PHP2D dapat terlaksana dengan baik.

\section{DAFTAR PUSTAKA}

Asse, Azlam, R., \& Ambo. (2018). Strategi Pemasaran Online (Studi Kasus Facebook Marketing Warunk Bakso Mas Cingkrank di Makassar). Jurnal Komunikasi, 7(2), 219-231.

Deoranto, P., \& Astusi, R. (2019). Pkm Kelompok Usaha Keripik Tempe Di Desa Tulungrejo, Kecamatan Bumiaji Dan Desa Beji, Kecamatan Junrejo, Kota Batu, Jawa Timur. Jurnal Teknologi Pangan, 10(1), 9-17. https:/ / doi.org/10.35891/tp.v10i1.1434

Dinar, F. (2013). Manfaat Tempe Terhadap Kesehatan Tubuh. Pengabdian Kepada Masyarakat, 19, 1-10.

Fadly, H. D., \& Sutama, S. (2020). Membangun Pemasaran Online Dan Digital Branding Ditengah Pandemi Covid-19. Jurnal Ecoment Global: Kajian Bisnis Dan Manajemen, 5(2), 213-222. http:/ / ejournal.uigm.ac.id/index.php/EG/article/view/1042

Jati, W., \& Yuliansyah, H. (2017). Pengaruh Strategi Pemasaran Online (Online Marketing Strategy) Terhadap Minat Beli Konsumen (Studi Kasus Pada Toko Online Shop Azzam Store). 1(1), 2598-2823.

Kusumaningsih, Sukardi, W. (2018). Studi Pengolahan Tempe Gembus Menjadi Keripik dengan Kajian Proporsi Tepung Pelapis. Jurnal Teknologi Pertanian 3(2): 78 - 84 Studi, 2, 78-84. https:// doi.org/10.16285/j.rsm.2007.10.006

Laksono, A. S., Marniza, \& Rosalina, Y. (2019). Karakteristik Mutu Tempe Kedelai Lokal Varietas Anjasmoro Dengan Variasi Lama Perebusan Dan Penggunaan Jenis Pengemas. Jurnal Agroindustri, 9(1), 8-18.

Maulidasari, C. D., \& Damrus. (2020). Dampak Pemasaran Online Di Era Covid-19. Jurnal Bisnis Dan Kajian Strategi Manajemen, 4(2), 233-245.

Nirmala Sari, Evy Maharani, S. K. (2017). Strategi Pemasaran Agroindustri Keripik Tempe Di Desa Buluh Rampai Kecamatan Seberida Kabupaten Indragiri Hulu. Angewandte Chemie International Edition, 6(11), 951-952., 5-24.

Nisa, K., Laili, A., Qolbiyatul, S., \& Suyanto, M. (2018). Strategi Pemasaran Online dan Offline. Abdikarya: Jurnal Karya Pengabdian Dosen Dan Mahasiswa, 01(1), 55-60.

Nurani, \& Widhajati, E. (2019). Pemasaran dengan konsep baru ini dapat membantu pelaku usaha menjangkau daerah pemasaran ke seluruh dunia dengan lebih cepat dan akurat. Strategi pemasaran. Jurnal Benefit, 6(1), 58-66.

Qgdqj, L. Q., \& Imanuel, O. J. (2013). Analisis Keputusan Pembelian Konsumen Melalui Media. 4(November).

Rimawati, M. (2015). Perwujudan Paguyuban Masyarakat Dan Nilai Kebersamaan Dalam Pengelolaan Desa Wisata Sambi Di Sleman. Mimbar Hukum - Fakultas Hukum Universitas Gadjah Mada, 27(1), 29. https:/ / doi.org/10.22146/jmh.15908

Shiratina, A., Indika, D. R., Komariyah, I., Kania, D., \& Solihin, E. H. (2020). Pemasaran Online Melalui Penerapan Iklan Secara Digital. Jurnal Sain Manajemen, 2(1), 15-23.

Siti, A. (2018). Chips Tempe Sebagai Makanan Ringan Alternatif Pengganti Junkfood. 323-334. Suknia, S. L., \& Rahmani, T. P. D. (2020). Proses Pembuatan Tempe Home Industry Berbahan Dasar Kedelai (Glycine max (L.) Merr) dan Kacang Merah (Phaseolus 
vulgaris L.) Di Candiwesi, Salatiga. Southeast Asian Journal of Islamic Education, 03(01), 59-76.

Sulistiyawati, E. S., \& Widayani, A. (2020). Marketplace Shopee Sebagai Media Promosi Penjualan UMKM di Kota Blitar. Jurnal Pemasaran Kompetitif, 4(1), 133. https:// doi.org/10.32493/jpkpk.v4i1.7087

Suryanti, F., \& Mediaswanti, K. A. (2017). Keripik Tempe Di Kecamatan Blimbing Kota Malang. Jurnal Aplikasi Sains Dan Teknologi, 1, 8-16.

Wahyujatmiko, S., \& Yon Hadi, I. (2018). Manajemen Pemasaran Online Makaroni Huhhah Yogyakarta. JBTI: Jurnal Bisnis Teori Dan Implementasi, 9(2), 100-120. https:// doi.org/10.18196/bti.92104

Yuliani, R., \& Widyakanti, W. (2020). Peningkatan Penjualan Melalui Inovasi Kemasan dan Label Pada UMKM. Jurnal Keuangan Umum Dan Akuntansi Terapan, 2(2), 71-76. http://jurnal.pknstan.ac.id/index.php/KUAT/article/view/990

\footnotetext{
*Angga Setiawan, M.Pd (Corresponding Author)

STKIP PGRI Trenggalek,

Jl. Supriyadi No. 22, Trenggalek, Jawa Timur, 66319, Indonesia

Email: anggasetiawan25.as@gmail.com

Herlina Puji Utami

STKIP PGRI Trenggalek,

Jl. Supriyadi No. 22, Trenggalek, Jawa Timur, 66319, Indonesia

Email: herlinapuji30@gmail.com

Putri Datalia Jatayu

STKIP PGRI Trenggalek,

Jl. Supriyadi No. 22, Trenggalek, Jawa Timur, 66319, Indonesia

Email: putrijatayu1102@gmail.com
} 